Ann. Biol. anim. Bioch. Biophys., 1977, 17 (2), 243-247.

\title{
Is a non steroid testicular substance also implicated in the maturation of gonadotropic function in the ram?
}

\author{
par J. PELLETIER, M. TERQUI, M. R. BLANC \\ with the technical assistance of Florence FOULON, A. CARATY and J. CI. POIRIER
}

Station de Physiologie de la Reproduction, I. N. R. A. Nouzilly, 37380 Monnaie

Summary. Lambs were either castrated at $2,13,19$ or 52 weeks of age or made cryptorchid at 2 weeks of age and then serially bled after an interval of at least 3 months. Plasma $\mathrm{LH}$ and unconjugated testosterone were measured by radioimmunoassays.

Two or 13-week castrated rams and 2-week cryptorchid rams showed a significantly higher LH release compared to 52 -week castrated rams $(11.9 \pm 1.28,12.4 \pm 1.30$ and $14.6 \pm 2.83 \mathrm{ng} / \mathrm{ml}$ vs $7.3+0.79 \mathrm{ng} / \mathrm{ml}$ respectively). $\mathrm{LH}$ in the $\overline{19}$-week castrated group was intermediate $(10.4+0.74 \mathrm{ng} / \mathrm{ml})$.

Circahoral LH pattern in 2 and 52-week castrated animals indicated that the previous difference could not be attributed to larger LH peaks in the 2-week castrated rams since the pulsatile LH pattern was rather similar in both groups.

Finally, plasma testosterone was the same in both cryptorchid and intact rams $(10.0 \pm$ 1.30 vs $7.4 \pm 3.45 \mathrm{ng} / \mathrm{m} /$ respectively).

Thus, it is likely that a factor originating from the tubules of the developing testes ensures a late and definitive maturation of the hypothalamo-hypophyseal axis, at least as far as the intensity of $\mathrm{LH}$ release is concerned.

In the ram lamb, LH and plasma festosterone levels are highly and positively correlated from 0 to 13 weeks of age and thereafter plasma LH decreases while plasma testosterone increases (Cotta et al., 1975). This change can be attributed to the maturation of the sensitivity of the hypothalamo-hypophyseal system to steroids (Courot et al. 1975). In order to understand the mechanism of this maturation, we have investigated the relationships between the testis and the LH secretion.

\section{Material and Methods.}

In all experiments, Prealpes du Sud rams born in spring were used.

Experiment I (table 1): Twenty-two rams were divided into five groups $\left(A_{1}, A_{2}, B\right.$, $C$ and $D$ ) according to age at castration and at blood collection. Every twenty minutes during six hours a jugular blood sample was collected from each ram. 
Experiment I/ (fig. 1) : Two rams from each $\mathrm{A}_{2}$ and $\mathrm{D}$ groups of Exp. I were chosen by ballot and submitted again to blood sampling from an indwelling catheter in the jugular vein every five minutes for eight hours.

TABLE 1

Influence of age at costration on $\mathrm{LH}$ release (Experiment I)

\begin{tabular}{cccccc}
\hline Group & \multicolumn{4}{c}{ Age at } \\
\cline { 3 - 5 } & $\begin{array}{c}\text { No. of } \\
\text { animals }\end{array}$ & $\begin{array}{c}\text { Castration } \\
\text { (weeks) }\end{array}$ & $\begin{array}{c}\text { Blood sampling } \\
\text { (months) }\end{array}$ & LH (ng/ml) \\
a
\end{tabular}

$\mathrm{LH}$ is expressed in $\mathrm{LH} \mathrm{M} 3$ equivalent to $1.8 \mathrm{NIH} \mathrm{S}$.

a : mean \pm standard error.

** $A_{1}+A_{2}$ vs $D: P<0.05 ; C$ vs $D: P<0.02$.

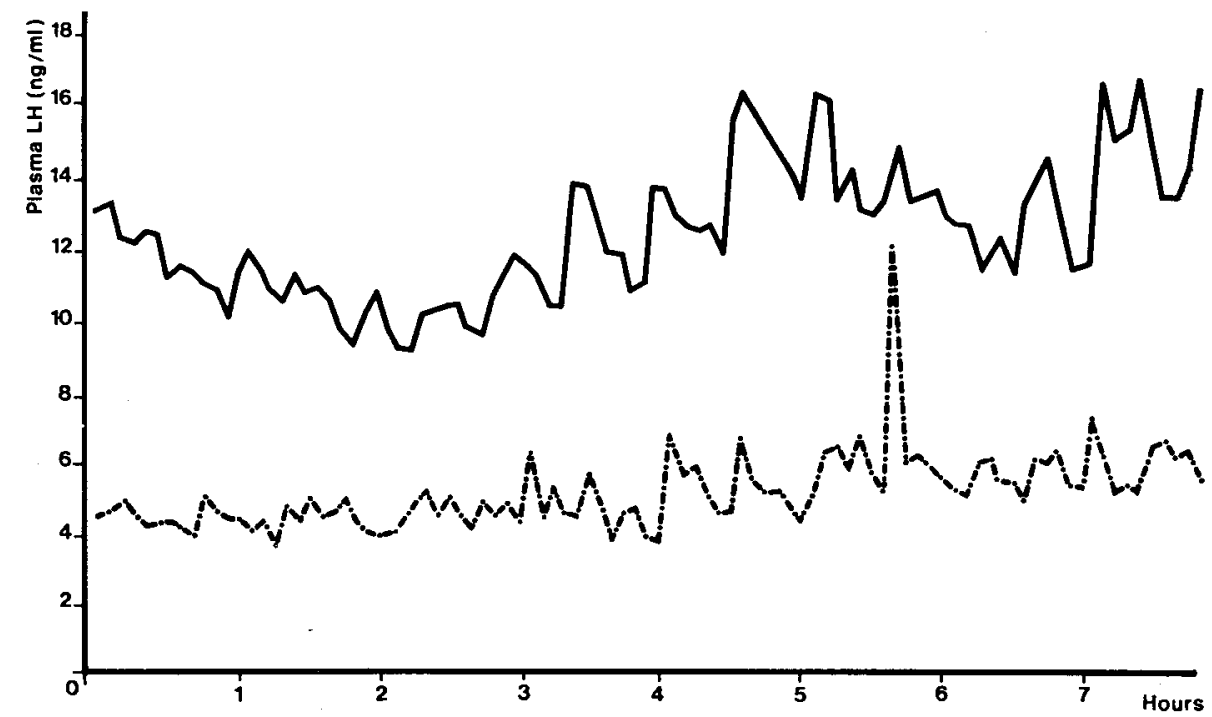

FIG. 1. - Plasma $L H$ release in two adult rams

Ram castrated at 2 weeks of age ( $A_{2}$ group).

Ram castrated at 52 weeks of age ( $D$ group). 
Experiment III (table 2) : Blood samples were taken every twenty minutes for six hours from four intact six month-old rams (controls : E group).

TABLE 2

Comparison of castration and cryptorchidism performed $A T 2$ weeks of age on $L H$ release

(Experiment III)

\begin{tabular}{|c|c|c|c|c|c|}
\hline Group & $\begin{array}{l}\text { No. of } \\
\text { animals }\end{array}$ & $\begin{array}{l}\text { Type of } \\
\text { surgery }\end{array}$ & $\begin{array}{c}\text { Age at blood } \\
\text { sampling (months) }\end{array}$ & $\underset{a}{\operatorname{LH}} \underset{\mathrm{a}}{(\mathrm{ng} / \mathrm{ml})}$ & $\begin{array}{l}\text { Testosterone } \\
(\mathrm{ng} / \mathrm{ml}) \mathrm{a}\end{array}$ \\
\hline $\begin{array}{l}E \\
F_{1} \\
F_{2} \\
A_{1} \\
A_{2}\end{array}$ & $\begin{array}{l}4 \\
4 \\
3 \\
4 \\
4\end{array}$ & $\begin{array}{l}\text { None } \\
\text { Cryptorchidism } \\
\text { Cryptorchidism } \\
\text { Castration } \\
\text { Castration }\end{array}$ & $\begin{array}{r}6 \\
6 \\
12 \\
3 \\
15\end{array}$ & $\begin{array}{l}1.5 \pm .23 * * \\
12.5 \pm 1.84 \\
14.6 \pm 2.83 \\
11.5 \pm 2.45 \\
12.3 \pm 1.28\end{array}$ & $\begin{array}{c}7.4 \pm 3.45 \\
10.0 \pm 1.30 \\
= \\
=\end{array}$ \\
\hline
\end{tabular}

$a$ : mean $t$ standard error.

** E vs $F_{1}: P<0.001: E$ vs $\AA_{1}: P<p .001$.

Four other rams were made cryptorchid surgically when two weeks old. Blood samples were collected as in $E$ group when six months old ( $F_{1}$ group) and again when 12 months old ( $F_{2}$ group). Blood sampling in $E$ and $F_{2}$ groups was done simultaneously with Exp. I groups.

In all experiments, plasma was kept at $-14^{\circ} \mathrm{C}$ until assayed for $\mathrm{LH}$ (Pelletier et al., 1968) and for unconjugated testosterone (Cotta et al., 1975).

Student $t$ test was used for paired analysis to compare groups.

\section{Results.}

Influence of the early castration on the $L H$ release (Exp. I, table 1).

After castration at 2 weeks of age, plasma LH levels at 3 or 15 months were much higher $(P<0,01)$ than those observed in rams castrated at 52 weeks of age and examined 6 months later $(\mathrm{Al}+\mathrm{A} 2: 11.9 \pm 1.28$ vs $\mathrm{D}: 7.3 \pm 0.79 \mathrm{ng} / \mathrm{ml})$. Animals castrated at 13 weeks of age (B group) have the same plasma LH levels as those operated on at 2 weeks of age $\left(A_{1}+A_{2}\right.$ groups). The levels are intermediate when operation took place at 19 weeks of age.

Influence of the age at castration on LH pattern (Exp. II).

Plasma LH patterns in two animals castrated at either 2 or 52 weeks of age were not clearly different as far as the numbers of $\mathrm{LH}$ peaks were concerned. Similarly, the magnitude of the peaks expressed in percentage of the mean LH levels was not different (fig. 1). Similar patterns were also observed in the two other castrated rams.

Furthermore, the mean plasma LH levels in each of the adult castrated rams was significantly lower than that observed in the young castrated rams. 
Comparison of castration and cryptorchidism performed at 2 weeks of age on the $L H$ release (Exp. III).

There was no difference in plasma LH levels $b$ : tween cryptorchid $\left(F_{1}+F_{2}\right.$ groups) and castrated rams ( $A_{1}+A_{2}$ groups) when surgery was performed at 2 weeks of age (table 2). Furthermore, the interval between surgery and blood sampling did not affect the mean $L H$ levels ( $F_{1}$ vs $F_{2}$ groups). However, each of these four groups was different $(P<0.001)$ from the intact rams (E group). Moreover, plasma testosterone levels (table 2) were high in cryptorchid rams $(10.0 \pm 1.3 \mathrm{ng} / \mathrm{ml})$ and were not different from those of intact rams $(7.4 \pm 3.45 \mathrm{ng} / \mathrm{ml})$.

\section{Discussion.}

The LH release was dependant on the age at which the animals were castrated (Exp. 1). Namely, the LH release after castration was about 70 p. 100 higher when surgery was carried out at two or thirteen weeks of age than at fifty two weeks. Thus, it appears that early orchidectomy induces a definite and permanent « extra secretion of LH » as compared with late castration. This extra secretion of LH did not concern the pulsatile pattern of secretion, namely the frequency or magnitude of LH peaks, but only mean basal level (Exp. II).

The extra secrefion of LH cannot be explained by an effect of the interval between castration and blood sampling : indeed, approximately three months after castration plasma LH level does not depend on the delay from surgery (Pelletier, unpublished) but varies only according to photoperiodism (Pelletier and Ortavant, 1975).

Furthermore, it must be pointed out that the same LH extra secretion was obtained in rams castrated at two weeks of age and in rams made cryptorchid at the same age while the latter showed plasma testosterone levels similar to intact animals up to 20 weeks (Blanc and Terqui, 1976). In the present experiments, no difference in plasma testosterone was observed in two-week cryptorchid rams serially sampled simultaneously with intact adult rams six months later.

Finally, it seems that a testicular factor, different from testosterone and absent and/or inactive before the thirteenth week of age, prevents the definitive maturation of the hypothalamo-hypophyseal system, indicated by the ability of the pituitary to produce the extra secretion of LH. That this factor originates from tubules rather than Leydig cells is suggested by the following : (i) plasma testosterone is already high in thirteen-week old lambs compared to adult rams (Crim and Geshwind, 1972 ; Cotta ef al., 1975) while castration at this age allows the extra secretion of $\mathrm{LH}$; (ii) this extra secretion occurs in two-week cryptorchid rams although plasma testosterone level is similar to intact rams (see above) ; (iii) conversely, the phenomenon of extra secretion of $\mathrm{LH}$ tends to decrease when castration is performed at nineteen weeks of age, which coincides with the establishement of the last steps of spermatogenesis (Courot, 1971).

Thus, an attractive hypothesis is that some elements of testis fubules secrete a factor which, in synergy or not with testosterone, provides an ultimate maturation of the hypothalamo-hypophyseal system as far as LH release is concerned. 
Acknowledgments. - Comments and helpful assistance in translation of the manuscript by Drs Courot M., Restall B. and Cahill L. are gratefully acknowledged.

Résumé. Des agneaux ont été castrés à l'âge de 2, 13, 19 ou 52 semaines et soumis à des séries de prélèvements de sang au minimum 3 mois après l'intervention. De plus, des agneaux ont été rendus chirurgicalement cryptorchides à l'âge de 2 semaines. La LH et la testostérone plasmatiques ont été mesurées par radio-immunologie.

Les taux de LH plasmatique chez les béliers castrés à l'âge de 2 ou 13 semaines, $(11,9 \pm 1,28$ et $12,4 \pm 1.30 \mathrm{ng} / \mathrm{ml})$ ou chez les béliers cryptorchides $(14,6 \pm 2,83 \mathrm{ng} / \mathrm{ml})$ sont significativement supérieurs à celui des béliers castrés à l'âge de 52 semaines $(7,3 \pm$ $0,79 \mathrm{ng} / \mathrm{ml}$ ). Cette différence ne résulte pas du profil de la décharge de LH dans le sang qui, au niveau près, a été trouvé approximativement le même chez des béliers castrés à l'âge de 2 semaines et chez ceux opérés à 52 semaines.

Enfin, le taux de testostérone plasmatique n'a pas été trouvé différent chez les béliers cryptorchides et les béliers intacts $(10,0 \pm 1,30$ vs $7,4 \pm 3,45 \mathrm{ng} / \mathrm{ml})$.

L'hypothèse la plus plausible pour rendre compte de l'ensemble de ces résultats consiste à supposer l'existence d'un facteur testiculaire originaire du compartiment tubulaire qui, dès avant la $19 \mathrm{e}$ semaine d'âge, provoquerait une ultime maturation du système hypotalamo-hypophysaire limitant définitivement la capacité de sécréter LH.

\section{References}

BLANC M. R., TERQUI M., 1976. Determination of the age of establishment of the inhibin-follicle stimulating hormone feed back mechanism in the ram lamb. IRCS Med. Sci., 4, 17.

COTTA M., TERQUI M., PELLETIER J., COUROT M., 1975. Testosterone et LH plasmatiques chez l'agneau de la naissance à la puberté, C. R. Acad. Sc., Paris, Ser. D, 280, 1473-1476.

COUROT M., 1971. Etablissement de la spermatogenèse chez l'agneau (Ovis aries). Etude expérimentale de son contrôle gonadotrope ; importance des cellules de la lignée sertolienne. Thèse Doc. Sci. Nat., Paris, No CNRS AO 6317, 200 pp.

COUROT M., de REVIERS M. M., PELLETIER J., 1975. Variations in pituitary and blood LH during puberty in the male lamb. Relation to time of birth. Ann. Biol. anim. Bioch. Biophys., 15, 509-516.

CRIM L. W., GESCHWIND I. I., 1972. Testosterone concentration in spermatic vein plasma of the developing ram. Biol. Reprod., 7, 42-46.

PELLETIER J., KANN G., DOLAIS J., ROSSELIN G., 1968. Dosage radioimmunologique de l'hormone lutéinisante plasmatique chez le mouton. Mise au point de la technique de dosage. C. R. Acad. Sc., Paris, Ser. D, 266, 2291-2294.

PELLETIER J., ORTAVANT R., 1975. Photoperiodic control of LH release in the ram, II. Lightandrogens interaction. Acta endocr., 78, 442-450. 